\title{
Trends in the prevalence of COPD in elderly individuals in an air-polluted city in Japan: a cross-sectional study
}

This article was published in the following Dove Medical Press journal: International Journal of COPD

\author{
Kenji Kotaki' \\ Hisao Ikeda ${ }^{2}$ \\ Takeshi Fukuda' \\ Kawano Yuhei ${ }^{3}$ \\ Fumiko Yuki ${ }^{4}$ \\ Masayuki Kawasaki ${ }^{5}$ \\ Kentaro Wakamatsu ${ }^{5}$ \\ Kenzo Sugahara ${ }^{6}$ \\ 'Department of Physical Therapy, \\ Faculty of Fukuoka Medical \\ Technology, Teikyo University, Omuta, \\ Japan; ${ }^{2}$ Department of Nursing, \\ Fukuoka Faculty of Fukuoka Medical \\ Technology, Teikyo University, Omuta, \\ Japan; ${ }^{3}$ Department of Medical \\ Technology, Fukuoka Faculty of \\ Fukuoka Medical Technology, Teikyo \\ University, Omuta, Japan; ${ }^{4}$ Faculty of \\ Nursing, Kwassui Women's University, \\ Oura, Japan; ${ }^{5}$ National Hospital \\ Organization, Omuta Hospital, Omuta, \\ Japan; ${ }^{6}$ Sugahara Hospital, Omuta, \\ Japan
}

Correspondence: Kenji Kotaki Department of Physical Therapy, Faculty of Fukuoka Medical Technology, Teikyo University, 6-22 Misaki-Machi, Omuta, Fukuoka 836-8505, Japan

Tel $+8 \mid 944888493$

Fax +8I 944557903

Email koutaki@fmt.teikyo-u.ac.jp
Purpose: The aim of this study was to examine the effects of exposure to air pollution and cigarette smoke on respiratory function, respiratory symptoms, and the prevalence of COPD in individuals aged $\geq 50$ years.

Patients and methods: We used spirometry and medical questionnaires to screen 433 individuals from Omuta City, Japan, an area with high levels of air pollution.

Results: Non smokers had a high estimated COPD prevalence rate of $16 \%$. Among smokers, the estimated prevalence of COPD was $29 \%$ in seniors (50- to 74 -years group) and $37 \%$ in the elderly ( $>75$ years group). We also found a correlation between levels of suspended particulate matter and COPD.

Conclusion: Both smoking and chronic exposure to air pollution ( $>5$ years) decreased respiratory function, exacerbated respiratory symptoms, and increased the prevalence of COPD. We strongly recommend periodic screening for the elderly patients to facilitate early detection of respiratory disease.

Keywords: diagnosis, primary care, screening

\section{Introduction}

COPD is a respiratory condition that develops from long-term exposure to air pollutants and through smoking. ${ }^{1}$ The worldwide prevalence of COPD is increasing, and the disease is expected to be the third leading cause of death by $2020 .^{2}$ The Japanese Respiratory Society's guidelines for the management of COPD list exogenous risk factors such as tobacco smoke, atmospheric pollution, passive smoking, exposure to chemical substances, and respiratory infection. ${ }^{3}$ Of these factors, fine particulate matter with an aerodynamic diameter of $\leq 2.5 \mu \mathrm{m}\left(\mathrm{PM}_{2.5}\right)$ is of particular concern. $\mathrm{PM}_{2.5}$ can penetrate deep into the lung tissue and precipitate a number of respiratory diseases, although the research showing a clear causal relationship between particulate matter and COPD is scant. ${ }^{4}$ A few studies have reported a relationship between long-term exposure to suspended particulate matter and impairment of respiratory function, but no correlations were found between exposure to $\mathrm{PM}_{2.5}$ and changes in respiratory function. ${ }^{5}$ While there is no clear correlation between exposure to atmospheric pollution and the development of COPD, exposure has been reported to exacerbate respiratory symptoms such as cough; chronic respiratory symptoms and a history of asthma may increase the risk of developing COPD. ${ }^{6}$

Aging is a factor that increases the prevalence of COPD. With age, the respiratory system's morphological and functional resistance weakens, leading to an increase in morbidity. ${ }^{7}$ According to the European Lung White Book, individuals aged 60-79 years 
display an increase in respiratory morbidity and a reduction in the ratio of $\mathrm{FEV}_{1} / \mathrm{FVC}^{8}{ }^{8}$

The current air pollution problem in Japan and its aging society are expected to result in increased COPD morbidity. In Omuta City (Fukuoka prefecture), the proportion of the population aged $\geq 75$ years is $35 \%$, representing a superaging society. ${ }^{9}$ We constructed a system for coordinating local clinics, hospitals, and medical associations to raise awareness, improve opportunities for early diagnosis, and characterize the state of COPD in the city, which had been officially designated an air-polluted region because of coalmining activities. Elderly residents are considered part of the coal-energy generation, affected by the burning of biomass fuel and other products of a high-growth period, such as dust and smoking. A high cumulative exposure rate leads to high rates of COPD morbidity. Although data on the prevalence of COPD in the elderly are available, there are few reports concerning respiratory symptoms, respiratory function, and morbidity among elderly individuals who have been chronically exposed to contaminants in air-polluted areas.

The purpose of this study was to examine respiratory function, respiratory symptoms, and the prevalence of COPD in elderly individuals exposed to air pollution, smoking, and related factors.

\section{Patients and methods}

\section{Study design and setting}

We carried out a total of 10 screenings for COPD in district 4 of Omuta City, among mass residential health screenings held between 2015 and 2018 . Of the 55,316 residents who underwent a screening, 721 were aged $>50$ years, and 433 of those individuals consented to undergo an examination for COPD.

\section{Clinical measurements}

We collected information on age, sex, height, weight, and body mass index (BMI) and measured FVC, percentage vital capacity, $\mathrm{FEV}_{1}$, and the $\mathrm{FEV}_{1} / \mathrm{FVC}$ ratio. Diagnoses were classified as bronchial asthma, chronic bronchitis, both bronchial asthma and chronic bronchitis, and others. The categories used for establishing smoking status were current smoker, former smoker, passive smoker, and never-smoker.

Subjects had to have resided or been employed in Omuta City for at least 5 years. We used a COPD questionnaire to classify the subjects suspected of having COPD (Figure 1) and performed a pulmonary function test, for which we used a spirometer (Autospiro AS-407; Minato Medical Science, Osaka, Japan), adhering to the guidelines of the Japanese
Respiratory Society. Measurements were taken before providing a bronchodilator, and subjects with a $\mathrm{FEV}_{1} / \mathrm{FVC}$ ratio of $\leq 70 \%$ and a score of at least 17 points on the questionnaire were considered possible COPD patients..$^{10}$ The estimated prevalence was calculated from the spirometry data. To assess the effect on the elderly, we classified the subjects further into two groups according to the Japanese health care system: the seniors (50- to 74-years group) and the elderly ( $>75$ years group).

\section{Air pollution monitoring}

We collected atmospheric data for concentrations of suspended particulate matter, $\mathrm{PM}_{2.5}$, nitrogen dioxide, and ozone for Omuta City for the period between December 2013 and March 2017. The data were obtained from Omuta City government.

\section{Statistical analyses}

The Shapiro-Wilk method was used to test for normality. The Mann-Whitney $U$ test was used for comparisons between subjects with and without suspected COPD. For other comparisons between groups, we performed multiplecomparison tests using ANOVA and the Steel-Dwass test. The Cochran-Armitage test for trend was used for the categorical smoking data, and the chi-squared test was used for disease risk. The significance level was set at $5 \%$, and PASW for Windows, version 18 (IBM Corporation, Armonk, NY, USA) was used for all statistical analyses.

\section{Ethical considerations}

This study was conducted in accordance with the Declaration of Helsinki. All subjects provided written informed consent before data collection began. The study protocol was approved by the ethics committee of Teikyo University Faculty of Fukuoka Medical Technology (approval number: 08072424-2).

\section{Results}

Four hundred and thirty-three individuals provided consent and participated in the COPD screening. Of these individuals, $67(15 \%)$ subjects scored 17 or more points on the COPD questionnaire and had an $\mathrm{FEV}_{1}$ measurement of $\leq 70 \%$ (Figure 2). The estimated prevalence of COPD in smokers was $29 \%$ among seniors (50- to 74 -years group) and $37 \%$ among the elderly ( $>75$ years group). The estimated prevalence of COPD in the passive-smoking group was $8 \%$ among seniors and $17 \%$ among the $>75$ years group. In the non-smoking group, the estimated prevalence was $9 \%$ among the 50 - to 74 -years group and $16 \%$ among the $>75$ years group (Table 1). Overall, the prevalence of COPD 


\begin{tabular}{|c|c|c|c|}
\hline \multicolumn{2}{|c|}{ Question } & \multirow{2}{*}{$\begin{array}{l}\text { Response choices } \\
40-49 \text { years }\end{array}$} & \multirow{2}{*}{$\begin{array}{c}\text { Points } \\
0\end{array}$} \\
\hline \multirow{4}{*}{1} & \multirow[t]{4}{*}{ What is your age in years? } & & \\
\hline & & $50-59$ years & 4 \\
\hline & & $60-69$ years & 8 \\
\hline & & $\geq 70$ years & 10 \\
\hline \multirow{4}{*}{2} & \multirow{4}{*}{$\begin{array}{l}\text { How many cigarettes do you currently smoke each day. } \\
\text { (if you are an ex-smoker, how many did you smoke each day)? } \\
\text { What is the total number of years you have smoked cigarettes? } \\
\text { Pack per day = cigarettes per day } / 20 \text { per pack } \\
\text { Pack-years = pack per day } \times \text { years smoked }\end{array}$} & $0-14$ pack-years & 0 \\
\hline & & 15-24 pack-years & 2 \\
\hline & & 25-49 pack-years & 3 \\
\hline & & $50+$ pack-years & 7 \\
\hline \multirow{3}{*}{3} & \multirow{3}{*}{$\begin{array}{l}\text { What is your weight in kilograms? } \\
\text { What is your height in meters? } \\
\text { BMI = weight in } \mathrm{kg} /(\text { height in } \mathrm{m})^{2}\end{array}$} & $\mathrm{BMI}<25.4$ & 5 \\
\hline & & $\mathrm{BMI}<25.4-29.7$ & 1 \\
\hline & & $\mathrm{BMI}>29.7$ & 0 \\
\hline \multirow{2}{*}{$\begin{array}{c}4 \\
(\mathrm{CF} 4)\end{array}$} & \multirow[t]{2}{*}{ Is your cough affected by weather? } & Yes & 3 \\
\hline & & No or no cough & 0 \\
\hline \multirow{2}{*}{$\begin{array}{c}5 \\
(\mathrm{CF} 5)\end{array}$} & \multirow[t]{2}{*}{ Do you suffer from sputum production in the absence of a cold? } & Yes & 3 \\
\hline & & No & 0 \\
\hline \multirow{2}{*}{6} & \multirow[t]{2}{*}{ Do you suffer from sputum production first thing in the morning? } & Yes & 0 \\
\hline & & No & 3 \\
\hline \multirow{2}{*}{$\begin{array}{c}7 \\
(\mathrm{CF} 7)\end{array}$} & \multirow[t]{2}{*}{ How often do you have any wheezing? } & Never & 0 \\
\hline & & Sometimes or often & 4 \\
\hline \multirow{2}{*}{8} & \multirow[t]{2}{*}{ Do you have or did you used to have any allergies? } & Yes & 0 \\
\hline & & No & 3 \\
\hline
\end{tabular}

Figure I IPAG Questionnaire.

Note: The figure was adapted from the study by Sichletidis L, Spyratos D, Papaioannou M, et al. A combination of the IPAG Questionnaire and PiKo- ${ }^{\circledR}$ flow meter is a valuable screening tool for COPD in the primary care setting. Prim Care Respir J. 201 I;20(2):184-189.10

Abbreviations: BMI, body mass index; IPAG, International Primary Care Airways Group.

Total population over 50 years in four towns of Omuta City $(n=55,316)$

Population aged over 50 years who underwent regular medical examination $(n=721)$

Population that participated in the screening procedure $(n=433)$

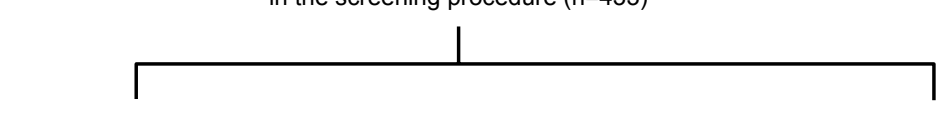

IPAG score $\geq 17(n=207)$

IPAG score $<17(n=226)$

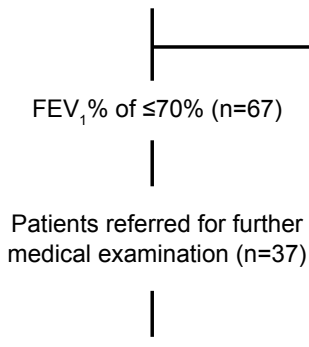

Patients who actually attended further medical examination $(n=20)$

Figure 2 Flowchart of the screening process.

Abbreviation: IPAG, International Primary Care Airways Group. 


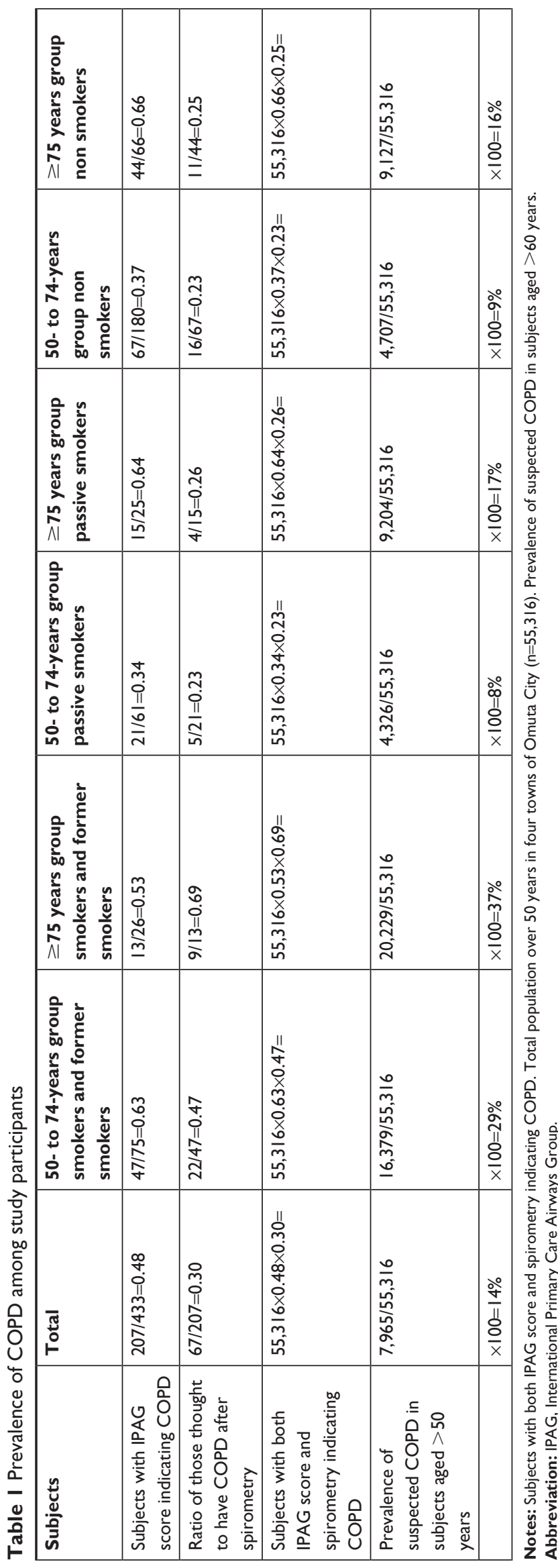

differed significantly between 50- to 74-years group and $>75$ years group (OR: 2.4, 95\% CI: 0.18-0.98; Table 2).

Respiratory function commonly deteriorates with age, and the $\mathrm{FEV}_{1} / \mathrm{FVC}$ ratio was lower in the elderly and lowest among $>75$ years group smokers $(72.7 \% \pm 11.2 \%, P<0.05$; Table 3$)$. Asforrespiratorysymptoms(Table4), itshowstheratioofthenumber of people who answered Yes. There was a significant difference between 50 - to 74 -years group and $>75$ years group smokers in wheezing, but not in coughing or sputum (Table 4).

Of the 37 patients with suspected COPD who were referred to local hospitals, only 20 actually underwent a formal diagnosis process. Follow-up showed that seven patients were diagnosed with COPD (35\%), six with bronchial asthma (30\%), two with lung cancer $(10 \%)$, and one with restrictive ventilatory impairment $(5 \%)$. The remaining four subjects were diagnosed with other conditions or with no abnormalities (20\%) (Table 5). Of the seven patients diagnosed with COPD, four were from Group A, two were from Group B, and one was from Group C. Of those diagnosed with bronchial asthma, one was from Group A, three were from Group B, one was from Group C, and one was from Group E.

The average $\mathrm{PM}_{2.5}$ values in Omuta City were 23.3, 19.4, and $20.9 \mu \mathrm{g} / \mathrm{m}^{3}$ in 2012, 2013, and 2014, respectively. The mean values of suspended particulate matter in those years were $24.4,23.8$, and $24.1 \mu \mathrm{g} / \mathrm{m}^{3}$. The Japanese environmental standards specify an average $\mathrm{PM}_{2.5}$ daily value below $35 \mu \mathrm{g} / \mathrm{m}^{3}$ and an annual average value below $15 \mu \mathrm{g} / \mathrm{m}^{3}$. The annual average value for Omuta City was therefore higher in 2012-2014 than the environmental standard (Figure 3). The WHO standard for $\mathrm{PM}_{2.5}$ is $25 \mu \mathrm{g} / \mathrm{m}^{3} / \mathrm{day}$, and the standard for the annual average is $10 \mu \mathrm{g} / \mathrm{m}^{3}$, lower than the Japanese standard. Japanese standards for daily average concentrations of nitrogen dioxide are within the range of $0.04-0.006 \mathrm{ppm}$ or less, and the workplace health and safety standard for ozone is $0.1 \mathrm{ppm}$ or less; the concentrations measured in Omuta City were well within the limits.

\section{Discussion}

We examined respiratory function, respiratory symptoms, and the prevalence of COPD in 50- to 74-years group and $>75$ years group individuals with chronic exposure to air pollution. An epidemiological survey of COPD prevalence conducted in Japan in 2001 reported an estimated prevalence of $8.5 \%$ overall, $12.4 \%$ for smokers, and $5 \%$ for non smokers. COPD prevalence was reported to be $5.1 \%$ for individuals in their $50 \mathrm{~s}, 12.2 \%$ for those in their $60 \mathrm{~s}$, and $17.4 \%$ for those aged $>70$ years. ${ }^{11}$ The $\mathrm{FEV}_{1} / \mathrm{FVC}$ ratio of non smokers was $79.9 \%$ and $77.5 \%$ for smokers. 
Table 2 ORs of COPD by age group and smoking status

\begin{tabular}{|c|c|c|c|c|c|c|c|}
\hline \multirow[t]{2}{*}{ Subjects } & \multicolumn{2}{|c|}{ 50- to 74 -years group } & \multicolumn{2}{|c|}{$\geq 75$ years group } & \multirow[t]{2}{*}{$P$-value } & \multirow[t]{2}{*}{ OR } & \multirow[t]{2}{*}{$95 \% \mathrm{Cl}$} \\
\hline & $(n=3 \mid 6)$ & & $(n=\mid 17)$ & & & & \\
\hline $\begin{array}{l}\text { Smokers and } \\
\text { former smokers }\end{array}$ & $22 / 53$ & $41 \%$ & $9 / 17$ & $52 \%$ & 0.56 & 1.07 & $0.35-2.46$ \\
\hline Passive smokers & $5 / 56$ & $9 \%$ & $4 / 21$ & $19 \%$ & 0.1 & 0.3 & $0.09-1.36$ \\
\hline Non smokers & $16 / 164$ & $10 \%$ & $11 / 55$ & $20 \%$ & $<0.04$ & 2.4 & $0.18-0.98$ \\
\hline
\end{tabular}

Note: The chi-squared test was used for calculating disease risk.

In the present study, elderly non-smoking individuals had a high estimated prevalence rate of $16 \%$, and rates in elderly individuals increased significantly from rates in seniors. We also found a correlation between levels of suspended particulate matter and COPD. Smokers and former smokers had an estimated prevalence rate of $>25 \%$ regardless of age, clearly showing the negative impact of smoking. The magnitude of the association we found between pollutant exposure and lung function is comparable to associations reported by studies that included pollution levels above the standards of the US Environmental Protection Agency. ${ }^{12}$ A study of 4,757 women in Germany found that a $7 \mu \mathrm{g} / \mathrm{m}^{3}$ increase in $\mathrm{PM}_{10}$ was associated with an increased prevalence of COPD (OR: $1.33,95 \%$ CI: 1.03-1.72). ${ }^{13}$

Morbidity, respiratory function, and respiratory symptoms are exacerbated with age. ${ }^{14}$ The prevalence of COPD among men aged $>40$ years is considered high and tends to increase rapidly aged $>60$ years. ${ }^{15}$ We found that the prevalence of COPD was high even among non smokers. With age, respiratory muscle strength is reduced, chest walls stiffen, leading to a reduction in thoracic compliance, and a decrease in lung capacity, and $\mathrm{FEV}_{1}$ is observed. In the elderly, pulmonary aging causes a decrease in $\mathrm{FEV}_{1}$ and enlargement of alveolar airspaces even in healthy individuals. ${ }^{16}$ Smokers, who are

Table 3 Characteristics of study participants and respiratory measurements

\begin{tabular}{|c|c|c|c|c|c|c|c|}
\hline \multirow{2}{*}{$\begin{array}{l}\text { Characteristics or } \\
\text { measurements }\end{array}$} & Group A & Group B & Group C & Group D & Group E & Group F & \multirow[t]{2}{*}{$P$-value } \\
\hline & $\begin{array}{l}50 \text { - to } \\
74 \text {-years } \\
\text { group } \\
\text { smokers } \\
\text { and former } \\
\text { smokers }\end{array}$ & $\begin{array}{l}\geq 75 \text { years } \\
\text { group } \\
\text { smokers } \\
\text { and former } \\
\text { smokers }\end{array}$ & \begin{tabular}{|l}
50 - to \\
74 -years \\
group \\
passive \\
smokers
\end{tabular} & $\begin{array}{l}\geq 75 \text { years } \\
\text { group } \\
\text { passive } \\
\text { smokers }\end{array}$ & $\begin{array}{l}50 \text { - to } \\
74 \text {-years } \\
\text { group } \\
\text { never- } \\
\text { smokers }\end{array}$ & $\begin{array}{l}\geq 75 \text { years } \\
\text { group } \\
\text { never- } \\
\text { smokers }\end{array}$ & \\
\hline Sex (male/female) & $56 / 19$ & $9 / 17$ & $6 / 55$ & $3 / 22$ & $48 / 132$ & $11 / 55$ & 0.75 \\
\hline \multirow[t]{2}{*}{ Age (years) } & $69.2 \pm 2.6$ & $77.8 \pm 2.5$ & $69.5 \pm 19.0$ & $78.6 \pm 4.1$ & $69.5 \pm 2.8$ & $78.9 \pm 3.1$ & $<0.001$ \\
\hline & & & & & & & $a, c, e, f, h, i, n,<0.001$ \\
\hline \multirow[t]{2}{*}{ Height (cm) } & $163.6 \pm 7.5$ & $161.0 \pm 10.2$ & $154.5 \pm 15.4$ & $153.1 \pm 7.6$ & $155.3 \pm 7.6$ & $152.5 \pm 7.5$ & $<0.001$ \\
\hline & & & & & & & $\mathrm{b}, \mathrm{c}, \mathrm{e}$ \\
\hline Weight (kg) & $59.3 \pm 8.6$ & $60.9 \pm 10.2$ & $53.4 \pm 14.7$ & $52.4 \pm 7.0$ & $55.3 \pm 10.2$ & $53.4 \pm 8.9$ & 0.39 \\
\hline Body mass index & $22.2 \pm 7.9$ & $23.5 \pm 9.8$ & $22.3 \pm 14.2$ & $22.38 \pm 7.3$ & $23.2 \pm 8.6$ & $23.11 \pm 8.9$ & 0.12 \\
\hline FVC (L) & $3.4 \pm 0.7$ & $3.1 \pm 0.9$ & $3.4 \pm 0.6$ & $2.4 \pm 0.7$ & $2.7 \pm 0.7$ & $2.4 \pm 0.7$ & 0.31 \\
\hline Percentage vital capacity & $102.9 \pm 27.6$ & $101.3 \pm 14.8$ & $102.9 \pm 24.4$ & $104.0 \pm 22.5$ & $99.8 \pm 16.7$ & $98.5 \pm 18.0$ & 0.12 \\
\hline \multirow[t]{2}{*}{$\mathrm{FEV}_{1}(\mathrm{~L})$} & $2.4 \pm 0.6$ & $2.1 \pm 0.6$ & $2.0 \pm 0.5$ & $1.8 \pm 0.6$ & $2.1 \pm 0.5$ & $1.7 \pm 0.5$ & $<0.00 \mathrm{I}$ \\
\hline & & & & & & & b, c, d, e, i, l, n, o \\
\hline \multirow[t]{2}{*}{$\mathrm{FEV}_{\mathrm{I}} / \mathrm{FVC}(\%)$} & $75.3 \pm 13.1$ & $72.7 \pm 11.2$ & $86.4 \pm 20.5$ & $77.8 \pm 15.3$ & $78.7 \pm I I .3$ & $77.7 \pm 11.9$ & $<0.05$ \\
\hline & & & & & & & $f, I$ \\
\hline $\begin{array}{l}\text { Suspected COPD } \\
\text { (male/female) }\end{array}$ & $22 / 53$ & $9 / 17$ & $5 / 56$ & $4 / 21$ & $16 / 164$ & $11 / 55$ & $<0.05$ \\
\hline
\end{tabular}

Notes: IPAG score, the COPD questionnaire score mean \pm SD of the group. CF4, IPAG fourth question about cough in the IPAG questionnaire. CF5, IPAG fourth question about sputum production in the IPAG questionnaire. CF7, IPAG fourth question about wheezing in the IPAG questionnaire. These show the ratio of the people who answered "Yes." A significant difference was seen only in wheezing ( $P<0.05$, Group A vs Group E). a, Group A vs. Group B; b, Group A vs. Group C; c, Group A vs. Group D; d, Group A vs. Group E; e, Group A vs. Group F; f, Group B vs. Group C; h, Group B vs. Group E; i, Group B vs. Group F; j, Group C vs. Group D; k, Group C vs. Group E; I, Group C vs. Group F; n, Group D vs. Group E; o, Group E vs. Group F. Values are presented as mean \pm SD. Differences in sample characteristics were analyzed for significance using ANOVA and a post-hoc test, the Mann-Whitney $U$ test, the Cochran-Armitage test, and the $\chi^{2}$ test.

Abbreviation: IPAG, International Primary Care Airways Group. 


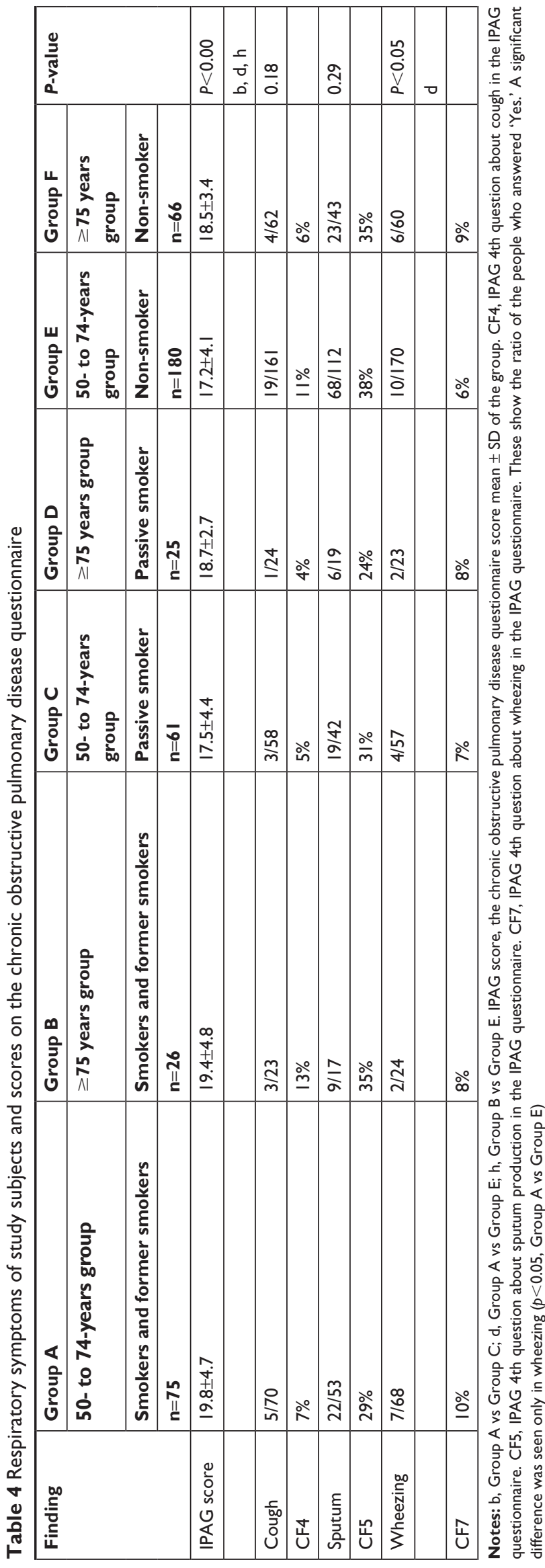

Table 5 Medical diagnoses of 20 study participants

\begin{tabular}{|l|l|}
\hline Diagnoses & Number of patients, $\mathbf{n}(\%)$ \\
\hline Bronchial asthma & $6(30)$ \\
\hline Lung cancer & $2(10)$ \\
\hline Pulmonary emphysema & $6(30)$ \\
\hline COPD & $\mathrm{I}(5)$ \\
\hline Restrictive ventilatory impairment & $\mathrm{I}(5)$ \\
\hline No abnormality & $2(10)$ \\
\hline Others & $2(10)$ \\
\hline
\end{tabular}

exposed to both air pollution and cigarette smoke, had an estimated prevalence of $>25 \%$ in our study.

We did not measure previous-day air pollution exposure or whether $\mathrm{FEV}_{1}$ varied by smoking status. We had sufficient power to evaluate effect modification by former smoking and found no evidence of heightened susceptibility to air pollution among former smokers.

The average annual values of $\mathrm{PM}_{2.5}$ concentrations in Omuta City are higher than international standards, and the proportion of the elderly in the population is $>35.7 \%$; the city is expected to see an increase in COPD patients. More than half of the subjects examined exceeded the cut off value in the COPD questionnaire, which was developed in Europe and the US, and so its usefulness in Japan has not been validated. ${ }^{17}$ It has been noted that using BMI as a variable is inappropriate in Japanese individuals and tends to yield higher results. In the subjects not suspected of having COPD, however, the proportion of complaints of cough, sputum, and wheezing exceeded $50 \%$, and it has been reported that these symptoms increase when $\mathrm{PM}_{2.5}$ concentrations exceed $20 \mu \mathrm{g} / \mathrm{m}^{3} .{ }^{18}$ In the US, COPD accounts for higher medical expenditures than other pulmonary diseases, ${ }^{19}$ and it is expected that it will also become a substantial economic burden in Omuta City. Early intervention and early diagnosis at the local-government level may reduce medical expenses. ${ }^{20}$

In this study, only 20 of the patients with suspected COPD who were referred to the central hospital for further diagnosis actually underwent a further medical examination. The number of COPD cases was relatively low (35\%). However, chronic bronchitis, bronchial asthma, emphysema, and other respiratory conditions were included in the COPD classification. Making a definitive diagnosis may be difficult, and an overlap of symptoms may be observed because of the complex presentation of these diseases.

There is evidence that the rate of awareness of COPD is lower among older individuals, who typically do not seek medical help until their symptoms are severe. ${ }^{21}$ Improving 


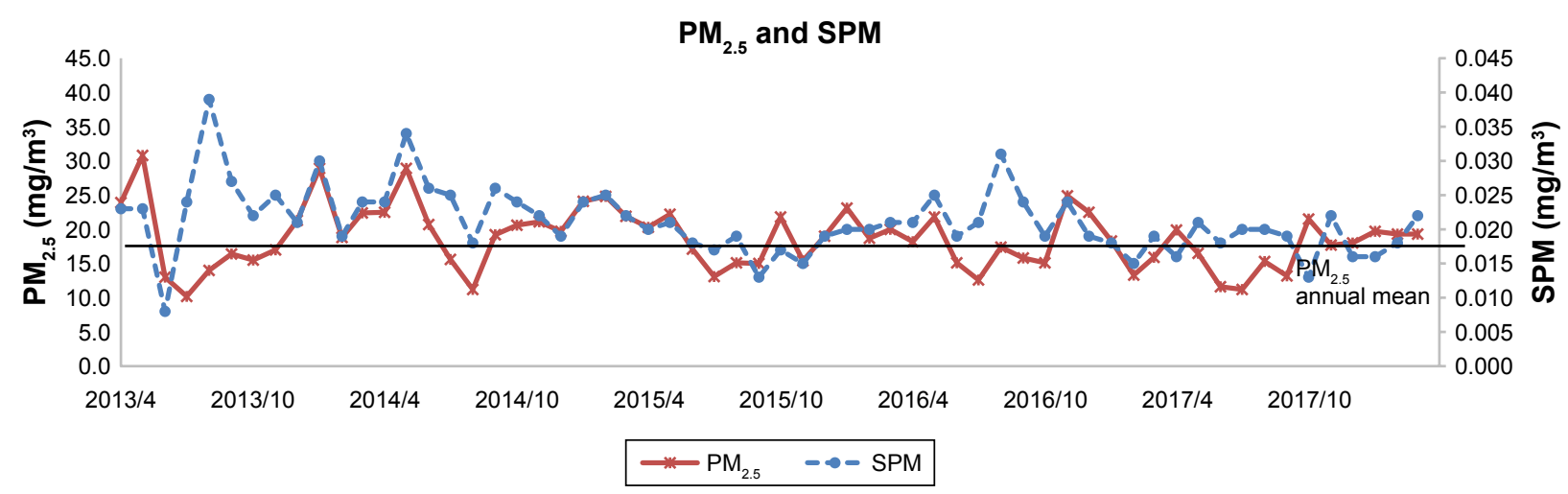

$\mathrm{NO}_{2}$ and $\mathrm{O3}$

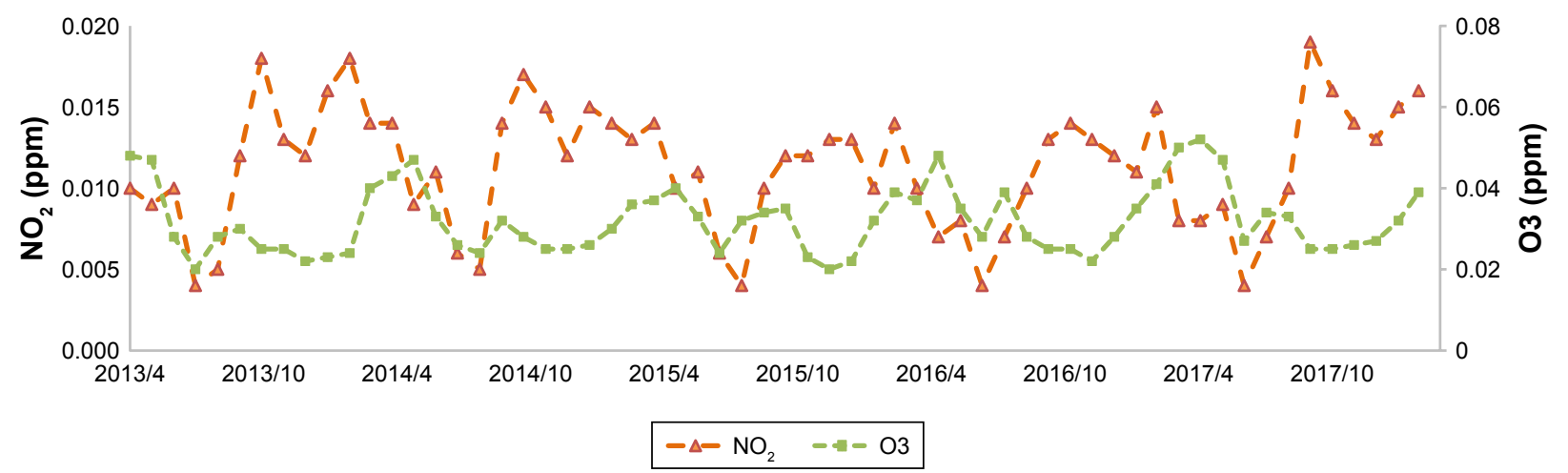

Figure 3 Air pollution monitoring.

Notes: The annual daily mean levels of $\mathrm{PM}_{2.5}$, SPM, $\mathrm{NO}_{2}$, and $\mathrm{O} 3$ were recorded from 2013 to 20I7. Information dissemination: Omuta City environment safeguard section. Abbreviations: $\mathrm{NO}_{2}$, nitrogen dioxide; $\mathrm{O} 3$, ozone; $\mathrm{PM}_{2.5}$, particulate matter with an aerodynamic diameter of $\leq 2.5 \mu \mathrm{m} ; \mathrm{SPM}$, suspended $\mathrm{PM}$..5

awareness of the causes and symptoms of COPD is essential for early detection of the disease. ${ }^{22}$ Furthermore, difficulty in accessing health care may have been a factor for older patients. It is likely that many COPD patients go undiagnosed; therefore, the elderly should undergo regular COPD screenings.

\section{Limitations}

As a limitation of this study, differences in air pollution exposure may have influenced the prevalence, and we did not have a control group. In addition, the exposure conditions, the levels of exposure in residential district environments, and the influence of the exposure period have not yet been investigated. The specific smoke-exposure history of current smokers, former smokers, and passive smokers was not taken into account, and neither had a family history of endogenous COPD factors. Nonetheless, the conclusions of the study are supported by appropriate evidence; the claims are not exaggerated.

\section{Conclusion}

We examined the effects of air pollution and smoking on respiratory function, respiratory symptoms, and trends of
COPD prevalence in the 50- to 74-years group and the $>75$ years group individuals. In addition to the impact of smoking, we verified that the elderly who were chronically exposed to air pollution had exacerbated respiratory symptoms and impaired respiratory function. Japan, with its aging population and air pollution issues, is expected to see an increase in the number of elderly individuals diagnosed with respiratory diseases. We strongly recommend that the elderly undergo periodic health screenings to facilitate early detection and that local governments enhance the provision of social security services such as patient education and smoking cessation programs.

\section{Acknowledgments}

The authors thank the study participants, technical staff, administrative support team, and our co-workers for their assistance. We thank the Omuta Public Health Center and Sugi Hospital for their support. We thank Dean Meyer, $\mathrm{PhD}$, ELS from Edanz Group (www.edanzediting.com/ac) for editing a draft of this manuscript. This work was supported by the Omuta Public Health Center and the National Hospital Organization Omuta Hospital. 


\section{Author contributions}

All authors contributed to data analysis, drafting and revising the article, gave final approval of the version to be published, and agree to be accountable for all aspects of the work.

\section{Disclosure}

The authors report no conflicts of interest in this work.

\section{References}

1. Rabe KF, Hurd S, Anzueto A, et al. Global strategy for the diagnosis, management, and prevention of chronic obstructive pulmonary disease: gold executive summary. Am J Respir Crit Care Med. 2007;176(6): $532-555$.

2. Price DB, Tinkelman DG, Halbert RJ, et al. Symptom-based questionnaire for identifying COPD in smokers. Respiration. 2006;73(3): 285-295.

3. Japanese Respiratory Society. The Japanese Respiratory Society guidelines for management of respiratory infections; 2018. Available from: http://www.jrs.or.jp/modules/guidelines/index.php?content_id=20. Accessed February 12, 2018.

4. Yang JY, Xin JY, Ji DS, Zhu B, Ds J. [Variation analysis of background atmospheric pollutants in North China during the summer of 2008 to 2011]. Huan Jing Ke Xue. 2012;33(11):3693-3704. Chinese.

5. Götschi T, Sunyer J, Chinn S, et al. Air pollution and lung function in the European community respiratory health survey. Int $J$ Epidemiol. 2008;37(6):1349-1358.

6. Hu G, Zhong N, Ran P. Air pollution and COPD in China. J Thorac Dis. 2015;7(1):59-66.

7. Fletcher C, Peto R. The natural history of chronic airflow obstruction. Br Med J. 1977;1(6077):1645-1648.

8. The European Respiratory Society's White Book [homepage on the Internet]. Available from: https://www.erswhitebook.org/. Accessed February 12, 2018.

9. Omuta-shi synthesis page the number of the households. Population. 2018. Available from: https://www.city.omuta.lg.jp. Accessed February 12, 2018.

10. Sichletidis L, Spyratos D, Papaioannou M, et al. A combination of the IPAG Questionnaire and PiKo- $6^{\circledR}$ flow meter is a valuable screening tool for COPD in the primary care setting. Prim Care Respir J. 2011;20(2):184-189.
11. Fukuchi $Y$, Nishimura M, Ichinose M, et al. COPD in Japan: the nippon COPD epidemiology study. Respirology. 2004;9(4):458-465.

12. World Health Organization. WHO Air quality guidelines for particulate matter, ozone, nitrogen dioxide and sulfur dioxide - global update. 2005. Available from: https://apps.who.int/iris/bitstream/handle/10665/69477/WHO_SDE_PHE_OEH_06.02_eng.pdf? sequence=1 . Accessed August 21, 2018.

13. Schikowski T, Sugiri D, Ranft U, et al. Long-term air pollution exposure and living close to busy roads are associated with COPD in women. Respir Res. 2005;6:152.

14. Sharma G, Goodwin J. Effect of aging on respiratory system physiology and immunology. Clin Interv Aging. 2006;1(3):253-260.

15. Li J, Sun S, Tang R, et al. Major air pollutants and risk of COPD exacerbations: a systematic review and meta-analysis. Int J Chron Obstruct Pulmon Dis. 2016;11:3079-3091.

16. Verbeken EK, Cauberghs M, Mertens I, et al. The senile lung. Comparison with normal and emphysematous lungs. 2. Functional aspects. Chest. 1992;101(3):800-809.

17. Kawayama T, Minakata Y, Matsunaga K, et al. Validation of symptombased COPD questionnaires in Japanese subjects. Respirology. 2008; 13(3):420-426.

18. Zemp E, Elsasser S, Schindler C, et al. Long-term ambient air pollution and respiratory symptoms in adults (SAPALDIA study). The SAPALDIA team. Am J Respir Crit Care Med. 1999;159(4 Pt 1):1257-1266.

19. Pope CA, Burnett RT, Turner MC, et al. Lung cancer and cardiovascular disease mortality associated with ambient air pollution and cigarette smoke: shape of the exposure-response relationships. Environ Health Perspect. 2011;119(11):1616-1621.

20. Tawara Y, Senjyu H, Tanaka K, et al. Value of systematic intervention for chronic obstructive pulmonary disease in a regional Japanese City based on case detection rate and medical cost. Int J Chron Obstruct Pulmon Dis. 2015;10:1531-1542.

21. Kornmann O, Beeh KM, Beier J, et al. Newly diagnosed chronic obstructive pulmonary disease. Clinical features and distribution of the novel stages of the global initiative for obstructive lung disease. Respiration. 2003;70(1):67-75.

22. Asai M, Tanaka T, Kozu R, et al. Effect of a chronic obstructive pulmonary disease (COPD) intervention on COPD awareness in a regional city in Japan. Intern Med. 2015;54(2):163-169.
International Journal of COPD

\section{Publish your work in this journal}

The International Journal of COPD is an international, peer-reviewed journal of therapeutics and pharmacology focusing on concise rapid reporting of clinical studies and reviews in COPD. Special focus is given to the pathophysiological processes underlying the disease, intervention programs, patient focused education, and self management protocols.

\section{Dovepress}

This journal is indexed on PubMed Central, MedLine and CAS. The manuscript management system is completely online and includes a very quick and fair peer-review system, which is all easy to use. Visit http://www.dovepress.com/testimonials.php to read real quotes from published authors. 